\title{
Csokoládéfogyasztás és a magyar Nobel-díjasok
}

\author{
Folyovich András dr. ${ }^{1}$ - Jarecsny Tamás dr. ${ }^{1}$ - Jánoska Dorottya dr. ${ }^{1}$ \\ Dudás Eszter dr. ${ }^{1}$ - Béres-Molnár Katalin Anna dr. ${ }^{1}$ - Botos Nóra dr. ${ }^{1}$ \\ Biczó Dávid dr. ${ }^{1,2}$ - Toldi Gergely dr. ${ }^{3}$
}

\author{
'Szent János Kórház és Észak-budai Egyesített Kórházak, Neurológiai Osztály, Stroke Centrum, Budapest \\ ${ }^{2}$ DRK Krankenhaus Neuwied, Németország \\ ${ }^{3}$ Semmelweis Egyetem, Általános Orvostudományi Kar, I. Szülészeti és Nőgyógyászati Klinika, Budapest
}

Bevezetés: Az étkezéssel fogyasztott növények egy részében jelentős mennyiségű flavonoid található, melyekről kimutatták, hogy javítják a kognitív funkciót. Egy korábbi elemzés alátámasztotta, hogy szoros szignifikáns lineáris korreláció mutatható ki az adott ország csokoládéfogyasztása és Nobel-díjasainak száma között. Ebben a vizsgálatban azonban Magyarország és a magyar Nobel-díjasok nem szerepelnek.

Célkitüzés: Jelen közleményünk célja ennek pótlása, a magyar adatok elemzése a nemzetközi adatok tükrében.

Módszer: A Nobel-díjasok országonkénti számát és a csokoládéfogyasztás nemzetközi adatait a fenti közlemény alapján vizsgáltuk. A csokoládéfogyasztás hazai mennyiségének meghatározása a Központi Statisztikai Hivatal adatain alapult. A vizsgált országok GDP-jének, valamint ezen összeg kutatásra fordított hányadának adatait a Világbank honlapjáról vettük át.

Eredmények: Magyarországon 11 Nobel-díjas élt. Ennek alapján a vizsgált 24 ország rangsorában Magyarországot a 9. hely illeti meg. Csokoládéfogyasztásban ugyanakkor a 19. helyezett. Összefüggést találtunk a Nobel-díjasok száma és az adott ország GDP-jének egy före eső hányada $(\mathrm{r}=0,734 ; \mathrm{p}=0,001)$, illetve a GDP kutatásra fordított hányada között $(\mathrm{r}=0,532 ; \mathrm{p}=0,01)$ között.

Következtetés: A magyar tudósok eredményei nem támasztják alá a korábban felvetett, a Nobel-díjasok száma (az adott ország kognitív szintje) és a csokoládéfogyasztás közti kapcsolatot. Életútjuk inkább a gazdagabb országok tudományt támogató nagyobb lehetőségeire világít rá.

Orv Hetil. 2019; 160(1): 26-29.

Kulcsszavak: csokoládéfogyasztás, flavonoidok, kognitív funkció, Nobel-díj

\section{Chocolate consumption and Hungarian Nobel laureates}

Introduction: Certain dietary items contain significant amounts of flavonoids which was shown to improve cognitive function. An earlier investigation demonstrated a strong linear correlation between chocolate consumption and the number of Nobel laureates in a given country. However, Hungary and the Hungarian Nobel laureates were not included in this analysis.

Aim: In this publication, we aim to complement these data by analyzing data available for Hungary.

Method: The number of Nobel laureates per country and the international data on chocolate consumption were based on the previously published results. The amount of chocolate consumption in Hungary was based on data from the Hungarian Central Statistical Office. GDP per capita and Research and Development Expenditure data for the investigated countries were derived from the World Bank.

Results: There are 11 Nobel laureates from Hungary. Based on this, Hungary ranks the 9th amongst the 24 studied countries. However, it only ranks the 19th when it comes to chocolate consumption. Correlations were found between the number of Nobel laureates and GDP per capita $(r=0.734 ; \mathrm{p}=0.001)$ as well as Research and Development Expenditure $(\mathrm{r}=0.532 ; \mathrm{p}=0.01)$ amongst the studied countries.

Conclusion: The achievements of Hungarian scholars do not support the earlier notion that there is a link between the number of Nobel laureates (cognitive function) and the chocolate consumption in a given country. Their biographies highlight the importance and more possibilities of research funding in wealthier countries.

Keywords: chocolate consumption, cognitive function, flavonoids, Nobel Prize

Folyovich A, Jarecsny T, Jánoska D, Dudás E, Béres-Molnár KA, Botos N, Biczó D, Toldi G. [Chocolate consumption and Hungarian Nobel laureates]. Orv Hetil. 2019; 160(1): 26-29.

(Beérkezett: 2018. július 29.; elfogadva: 2018. augusztus 4.) 


\section{Rövidítések}

GDP $=$ (gross domestic product) bruttó hazai össztermék; $\mathrm{KSH}=$ Központi Statisztikai Hivatal

Az étkezéssel fogyasztott növények egy részében jelentős mennyiségű flavonoid található, melyekrôl kimutatták, hogy javítják az agymúködést. Rendszeres fogyasztásuk csökkenti a dementia kockázatát, és javítja a teljesítményt bizonyos kognitív tesztekben. Vascularis hatásuk is van, javítják az endothelfunkciót, és vasodilatatio révén csökkentik a vérnyomást [1]. Egyik csoportjukba tartoznak a flavonolok, amelyek megtalálhatók többek között a kakaóban, mely a csokoládé alapanyaga. A csokoládé és az agymúk ödés közötti összefüggést - a szakirodalomban az elsők között - K. Mátyus István már 1762-ben felvetette a Kolozsvárott megjelent „Diaetetica, az az, a jó egészség meg-tartásának módját, fundamentumosan elő-adó könyv” címú munkájának „első darab”-jában: „(a csokoládé) igen bőven táplál... jóféle vékony vért csinál... az agyvelőt erősíti..." Mátyus könyvére a szakirodalom is felfigyelt [2]. Almási Balogh Pál „A’ kávé, thé és csokoládé történeti, természethistóriai, diaeteticai és orvosi tekintetben" címmel 1831-ben monográfiát jelentetett meg a témában. Matos Lajos és Lengyel Margit közelmúltban megjelent közleményében a csokoládét „alapvető fizikai és pszichés múködéseket befolyásoló farmakon"-nak tekinti [3].

Franz H. Messerli a The New England Journal of Medicine-ben 2012-ben elemezte az egyes országok 10 millió lakosára jutó Nobel-díjasainak számát, összevetve az adott ország egy főre eső csokoládéfogyasztásával [4]. Megállapította, hogy szoros szignifikáns lineáris korreláció mutatható ki az adott ország csokoládéfogyasztása és Nobel-díjasainak száma között. Eredményének elméleti megalapozását látta a flavonoidok (a csokoládé) pozitív hatásában, mely nemcsak az egyén, de az egész populáció szintjén is jó hatással lehet a kognitív funkcióra. Úgy vélte, hogy a kimutatott korrelációban az országok eltérô szocioökonómiai státusza, a földrajzi és klimatikus tényezők bizonyos szerepet játszhatnak, de a szoros összefüggések magyarázatául teljes egészében nem tehetők felelőssé. Felvetette, hogy az egy főre eső csokoládéfogyasztás megfeleltethető az adott népesség kognitív szintjével, mely utóbbit közvetve a Nobel-díjasok száma jelezheti. Messerli munkájában Magyarország és a magyar Nobel-díjasok nem szerepelnek. Jelen közleményünk célja ennek pótlása, a magyar adatok elemzése a nemzetközi adatok tükrében.

\section{Módszer}

A Nobel-díjasok országonkénti számát és a csokoládéfogyasztás nemzetközi adatait Messerli közleményéből vettük át [4]. Messerli közleményének módszertanát követve a magyar Nobel-díjasok számát a Wikipédia adatai alapján határoztuk meg [5]. Az itt nyilvántartott 13 tu-
1. táblázat |Az elemzésben szereplő magyar Nobel-díjasok

\begin{tabular}{lll}
\hline A kitüntetett neve & A díjazott terület & A díj odaítélésének éve \\
\hline Lénárd Fülöp & Fizika & 1905 \\
Bárány Róbert & Orvostudomány & 1914 \\
Zsigmondy Richárd & Kémia & 1925 \\
Szent-Györgyi Albert & Orvostudomány & 1937 \\
Hevesy György & Kémia & 1943 \\
Békésy György & Orvostudomány & 1961 \\
Wigner Jenő & Fizika & 1963 \\
Gábor Dénes & Fizika & 1971 \\
Harsányi János & Közgazdaságtan & 1994 \\
Oláh György & Kémia & 1994 \\
Kertész Imre & Irodalom & 2002 \\
\hline
\end{tabular}

dós közül kettő nem került feldolgozásra, mert vagy nem élt Magyarországon, vagy nem tartotta magát magyarnak. Bekerültek viszont azok, akik az úgynevezett történelmi Magyarországon éltek, így abban a tradícióban nevelkedtek (1. táblázat).

A csokoládéfogyasztás hazai mennyiségének meghatározása a Központi Statisztikai Hivatal $(\mathrm{KSH})$ adatain alapult.

A vizsgált országok bruttó hazai össztermékének (GDP) 2017-es, valamint az ezen összeg kutatásra fordított hányadának 2011. évi adatait a Világbank honlapjáról vettük át $[6,7]$.

Az összefüggések elemzésére Spearman-féle rangkorrelációt alkalmaztunk.

\section{Eredmények}

Elemzésünkben 11 magyar Nobel-díjas szerepel, így a 10 millió főre jutó Nobel-díjasok száma Magyarországon 11,02. Ennek alapján a vizsgált országok rangsorában Magyarországot a 9. hely illetné meg. Csokoládéfogyasztásban ugyanakkor Magyarország a vizsgált 24 ország közül a 19. helyezett (1.ábra).

Összefüggést találtunk a Nobel-díjasok száma és az adott ország GDP-jének egy főre eső hányada $(\mathrm{r}=0,734$; $\mathrm{p}=0,001)(2 / a$ ábra $)$, illetve a GDP kutatásra fordított hányada $(\mathrm{r}=0,532 ; \mathrm{p}=0,01)(2 / b$ ábra $)$ között.

\section{Megbeszélés}

Messerli véleménye szerint a csokoládéfogyasztás elméletileg nemcsak az egyén, de az egész populáció szintjén is jó hatással lehet a kognitív funkcióra [4]. Az egy főre eső csokoládéfogyasztásból az adott népesség kognitív szintjére igyekezett következtetni, mely utóbbit közvetve a Nobel-díjasok száma jelezheti. Szerinte ez tükrözi a legmagasabb szintű szellemi funkcióra képes személyek arányát, ezáltal közvetve az adott ország átlagos szellemi teljesítményének mértékéül is szolgálhat. Eredményeit 


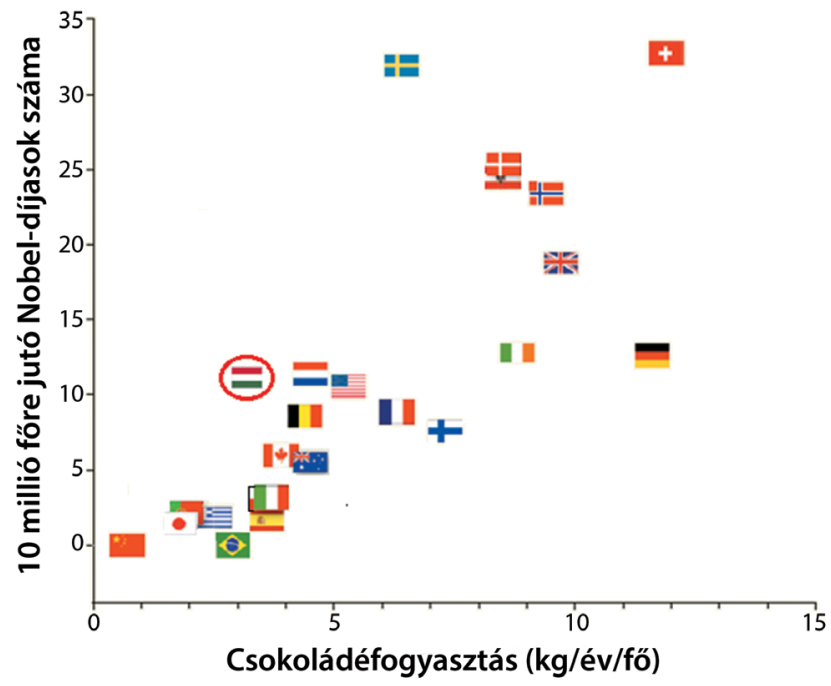

1. ábra

A 10 millió főre jutó Nobel-díjasok száma az adott ország csokoládéfogyasztásának függvényében. A Messerli eredeti közleményében [4] szereplő 23 ország mellett Magyarország is feltüntetésre került, piros karikával jelölve

grafikusan is ábrázolva megállapította, hogy szoros szignifikáns lineáris korreláció $(\mathrm{r}=0,791 ; \mathrm{p}<0,0001)$ mutatható ki az adott ország csokoládéfogyasztása és Nobeldíjasainak száma között. Az egyes országok Nobel-díjasainak számát a Wikipédia alapján, az egy före eső csokoládéfogyasztást kereskedelmi cégek adatai alapján állapította meg 23 országot vizsgálva. Megadta azt is, hogy a csokoládéfogyasztás milyen mértékű növekedése emeli a Nobel-díjasok számát, sőt a minimálisan hatásos csokoládé mennyiségét is. Leszögezte ugyanakkor, hogy a korreláció nem jelent egyben ok-okozati kapcsolatot. Véleményét erősítette az, hogy nem talált olyan közös (például szociális, geográfiai, klimatikus) okot, mely a csokoládéfogyasztást és a Nobel-díjasok számát együttesen befolyásolná. Utalt ugyanakkor arra a lehetőségre is, hogy a kapcsolat fordított is lehet: a jobb kognitív teljesítmény nagyobb csokoládéfogyasztásra serkent, mert a jobb kognitív funkciójú személyek egészségtudatosabbak, és több csokoládét fogyasztanak a benne levő flavonolok kedvező hatása miatt.

a)

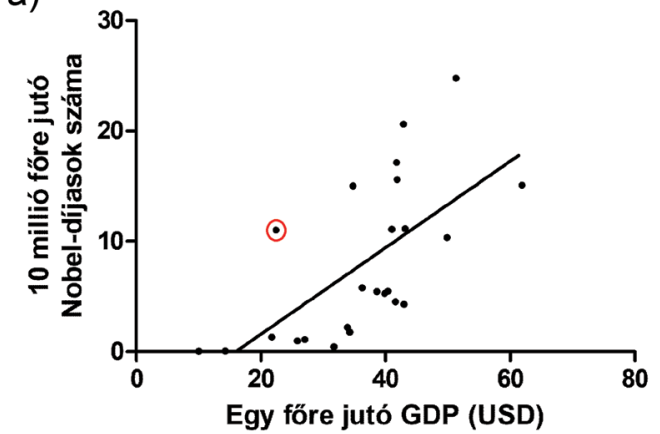

Messerli munkájában a magyar Nobel-díjasok nem szerepeltek. Miután Magyarország lélekszáma közel 10 millió, az általunk számon tartott 11 Nobel-díjassal a felsorolt országok között a 9. helyen kellett volna szerepelnie. Csokoládéfogyasztásban ugyanakkor a 19. helyezett. Ennek alapján a magyar Nobel-díjasok jóval kevesebb csokoládét fogyasztottak, mint a korreláció alapján várható lett volna.

Közismert, hogy Magyarország történelme során több olyan periódus volt, amikor tömegesen hagyták el az országot a magyarok, így neves tudósok is. A Nobel-díj odaítéléséról ismert az is, hogy az elismerést gyakran 20-30 évvel a díjazott tudományos eredményt követően kapják meg, amikor a díj elnyerője esetleg már nem saját hazájában él. Messerli véleményének megítélésében fontos szempont, hogy mennyire változik meg egy új hazát választó személy étkezési szokása, mely nyilvánvalóan magában foglalja a csokoládéfogyasztás mértékét is. Az irodalmi adatok megerősítették feltételezésünket, hogy új környezetbe kerülő személyeknél életük későbbi szakaszában is az anyaország táplálkozási szokásai a meghatározóak. A táplálkozási szokások jóval lassabban változnak, mint más asszimilációs jellemzők (mint például a nyelv, öltözködés), mert az ételekhez való kötődés mélyen gyökerező személyes jellemző, egyúttal egyedi és alapvető jellemzője a kultúrának. Mindez leképeződik a generációk táplálkozásból eredő cardiovascularis kockázatában [8-10]. Mindezek alapján úgy gondoljuk, hogy a külföldre került magyar Nobel-díjasok csokoládéfogyasztása az őshaza szokásaival egyező.

Mi lehet akkor a valós ok, mely mind a Nobel-díjas tudósok magasabb számára, mind a csokoládéfogyasztásra kedvező hatással van? Erre a kérdésre keresve a választ, vizsgáltuk az adott ország gazdasági teljesítményét és a kutatásra fordított támogatás mértékét. Amennyiben megvizsgáljuk az egyes országok GDP-jének egy före eső hányadát, továbbá elemezzük a GDP-nek a tudományra fordított arányát, akkor ezen tényezők szerepe látszik igazolódni. Adott esetben ez a közvetett oka annak, hogy egy kiemelkedő képességű kutató pályáját gazdagabb országban folytatja, ott éri el kimagasló tudomá-

b)

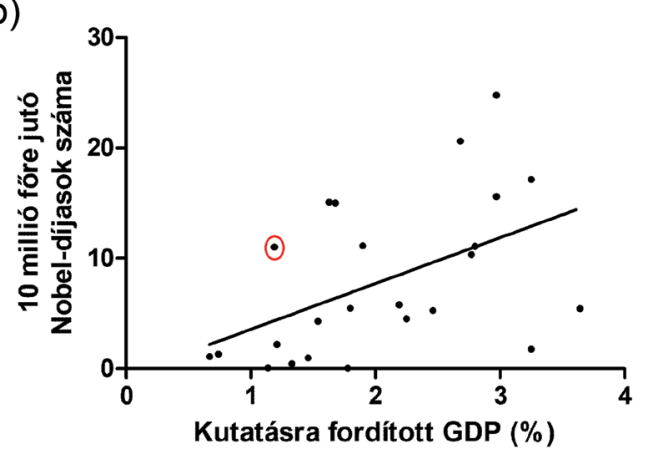


nyos eredményeit, és kapja meg az őshazában megalapozott teljesítményéért a Nobel-dijat.

Messerli és saját eredményeinket befolyásolhatja, hogy a Nobel-díjasok listája az elmúlt több mint 100 évre, míg a csokoládéfogyasztás és a gazdasági adatok döntően az elmúlt 10 évre vonatkoznak, mely időpontban nyilván egészen más életszínvonalon éltek egy adott ország lakói. A legfrissebb gazdasági és fogyasztási mutatók nem feltétlenül vethetők össze az adott ország 100 évre viszszamenő körülményeivel.

\section{Következtetés}

A magyar tudósok eredményei nem támasztják alá a korábban felvetett, a Nobel-díjasok száma (az adott ország kognitív szintje) és a csokoládéfogyasztás közti kapcsolatot. Életútjuk inkább a gazdagabb országok tudományt támogató nagyobb lehetőségeire világít rá.

Anyagi támogatás: A közlemény megírása, illetve a kapcsolódó kutatómunka anyagi támogatásban nem részesült.

Szerzői munkamegosztás: F. A., D. E.: Vizsgálati koncepció, irodalomkutatás. F. A., J. D., B. D.: Adatgyújtés, statisztikai elemzés. F. A., B.-M. K. A.: A kézirat megírása. J. T., B. D., T. G.: A kézirat ellenőrzése, korrektúrázása. B. N., T. G.: Az ábrák készítése. A cikk végleges változatát valamennyi szerző elolvasta és jóváhagyta.

Érdekeltségek: A szerzőknek nincsenek érdekeltségeik.

\section{Irodalom}

[1] Kerimi A, Williamson G. The cardiovascular benefits of dark chocolate. Vascul Pharmacol. 2015; 71: 11-15.

[2] Kempler K. The history of medicaments. [A gyógyszerek története.] Gondolat Könyvkiadó, Budapest, 1984; p. 87. [Hungarian]

[3] Matos L, Lengyel M. Chocolate. [Csokoládé.] Lege Artis Med. 2006; 12: 1089-1092. [Hungarian]

[4] Messerli FH. Chocolate consumption, cognitive function, and Nobel laureates. N Engl J Med. 2012; 367: 1562-1564.

[5] List of Nobel laureates by country. Available from: https:// en.wikipedia.org/wiki/List_of_Nobel_laureates_by_country [accessed: July 25, 2018].

[6] GDP per capita. Available from: https://data.worldbank.org/ indicator/NY.GDP.PCAP.PP.KD [accessed: July 25, 2018].

[7] Research and development expenditure. Available from: https:// data.worldbank.org/indicator/GB.XPD.RSDV.GD.ZS?end= 2011\&start=2010\&year_high_desc=false [accessed: July 25, 2018].

[8] Sharma S, Cade J, Riste L, et al. Nutrient intake trends among African-Caribbeans in Britain: a migrant population and its second generation. Public Health Nutr. 1999; 2: 469-476.

[9] Park SY, Paik HY, Skinner JD, et al. Mothers' acculturation and eating behaviors of Korean American families in California. J Nutr Educ Behav. 2003; 35: 142-147.

[10] Guendelman S, Abrams B. Dietary intake among MexicanAmerican women: generational differences and a comparison with white non-Hispanic women. Am J Public Health 1995; 85: 20-25.

(Toldi Gergely dr., Budapest, Baross u. 27., 1088 e-mail: toldigergely@yahoo.com)

\section{"Nemo propheta in patria sua." (Senki sem próféta a saját hazájában.)}

A cikk a Creative Commons Attribution 4.0 International License (https://creativecommons.org/licenses/by/4.0/) feltételei szerint publikált Open Access közlemény, melynek szellemében a cikk bármilyen médiumban szabadon felhasználható, megosztható és újraközölhető, feltéve, hogy az eredeti szerző és a közlés helye, illetve a CC License linkje és az esetlegesen végrehajtott módosítások feltüntetésre kerülnek. (SID_1) 